\title{
Artículo Especial: Obras maestras del arte universal y la medicina: "Crimen y castigo" de Fedor Dostoievski (1821-1881)
}

\section{Argumento}

Rodion Raskolnikov, un estudiante sumido en la miseria por propia voluntad, asesina premeditadamente a una vieja prestamista usurera y despiadada, a quien él había recurrido por dinero. Durante el hecho, se ve obligado a asesinar también a la hermana de la anciana, ya que ésta lo sorprende en el lugar del hecho. Sin embargo, el móvil de su crimen no es el robo, sino su convicción de que dicho asesinato constituye un servicio a la sociedad. No obstante, tras cometer dicho homicidio, lejos de sentirse satisfecho, se recrimina el haberse arruinado la vida sin razón, y comienza a ser víctima de impulsos auto-incriminatorios que lo llevan no sólo a confesar su delito a su amada (Sonia) y a su hermana, sino incluso a darle a entender entrelíneas su culpabilidad al mismísimo juez de instrucción. Finalmente, tras tornársele insoportable el peso de la culpa y ante la imposibilidad de suicidarse decide, a pesar de no haber pruebas en su contra y que incluso un inocente se ha declarado culpable, confesar su delito y entregarse a la justicia. Es entonces condenado a trabajos forzados en Siberia, lugar al que Sonia lo acompaña por amor.

\section{Ejemplo en el Texto}

"... no consigo explicarme por qué fui allí, ni por qué hice lo que hice ..."

"Aquel hombre obró tan sólo llevado por su sed de expiación: quería sufrir ese castigo"

\section{Análisis de la obra}

La principal "víctima" en esta obra es Raskolnikov, quien resulta el verdugo de sí mismo, al ser el artífice de sus penurias (miseria, crimen), de modo que termina recibiendo un castigo (prisión) que no es más que consecuencia de sus propios actos, castigo que inconscientemente creía merecer desde antes del homicidio y cuya concreción sólo tornó justificable desde un plano consciente. En esta obra, Dostoievski delinea uno de los aspectos más enigmáticos de la naturaleza humana, y que consiste en que en nuestra especie mora un sentimiento de culpa que antecede al delito. Una culpa primordial que ya se encuentra incluso plasmada en el orden litúrgico (pecado original). Desde la teoría freudiana se ha intentado explicar el origen de esta culpa: por un lado en el plano grupal, se la considera consecuencia del parricidio primitivo y el remordimiento derivado del mismo (Totem y Tabú), mientras que en el plano individual se la considera nacida de la distancia abismal existente entre la realidad de uno mismo y el ideal del Yo, es decir entre lo que uno es y aquello que se propone ser sin ninguna restricción. La constatación de dicha distancia genera culpa, la cual deviene en una dosis letal de pulsión de muerte que termina por direccionarse contra uno mismo (conductas autodestructivas) o contra el prójimo (el delito y sus matices). Asimismo, el apellido Raskolnikov, evoca la palabra rusa rasko: escisión, que alude precisamente a que el protagonista se encuentra "escindido" entre quien él es (un simple estudiante) y quien creyó ser (un hombre por encima de la ley) y quien terminó siendo (un vulgar homicida).

\section{La falta de adherencia terapéutica y auto-castigo}

La buena adherencia del paciente al tratamiento prescripto, como ya hemos analizado en otros artículos de esta serie ("El malentendido" de Camus' y "Pigmalión" de Shaw²), es el resultado en gran parte del desarrollo de una efectiva comunicación, y una adecuada atmósfera empática. Sin embargo ante la presencia de una mala adherencia nunca debe soslayarse el papel que puede jugar la existencia en el paciente de un sentimiento inconsciente de culpa, junto a la convicción de merecer por ello "un justo castigo", encarnado en la mala evolución clínica (autofomentada) de la enfermedad que lo aqueja y que paradójicamente motivó la consulta. Se trata de una "necesidad de castigo" de la cual no hay auto-conciencia y que es más propiedad de la especie que del propio individuo que la padece. El conocimiento de la existencia de este pasaje en el laberinto de la naturaleza humana, contribuye a su identificación y a orientar al paciente a recibir la ayuda psicológica profesional necesaria a fin de desarticular este sentimiento que atenta contra su mejoría. Concluimos entonces que la obra "Crimen y Castigo" de Fedor Dostoievski es de suma importancia para comprender la existencia del sentimiento de culpa primordial que se encuentra arraigado en la naturaleza humana, y cómo éste puede justificar la aparición de conductas autodestructivas.

Musso C. Obras maestras del arte universal y la medicina: Crimen y Castigo de Fedor Dostoievski 1821 -1881. Evid Act Pract Ambul. Oct-Dic $2011 ; 14(4): 137$

\section{Referencias}

1. Musso C. Obras maestras del arte universal y la medicina: "El malentendido" de Albert Camus (1913-1960). Evid Act Pract Ambul. Mar-Abr 2008:11(2):48 2. Musso C. Obras maestras del arte universal y la medicina: "Pigmalión" de George Bernard Shaw (1856-1950). Evid Act Pract Ambul. Jul-Ago 2008:11(4):114.

\section{Otras lecturas recomendadas}

Amalfi F. El taller de los escritores. Inspiraciones sobre el arte de escribir, la literatura y la vida. Barcelona. Editorial Océano. 2005

Troyat H. Dostoievski. Barcelona. Vergara. 2006

Gourfinkel N. Dostoievski. Buenos Aires. Centro Editor de América Latina. 1986

Tello N. Dostoievski. Maestro de la mirada psicológica. Buenos Aires. Longseller.2002

Allen W. Match Point. 2004 (film)

Freud S. Obras Completas. Buenos Aires. Editorial El Ateneo. 2003

Bloom H. Genios. Bogotá. Grupo Editorial Norma. 2002

Onfray M. Antimanual de filosofía. Madrid. Edaf Ensayo. 2005 